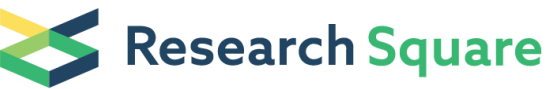 \\ Preprints are preliminary reports that have not undergone peer review. \\ They should not be considered conclusive, used to inform clinical practice, or referenced by the media as validated information.
}

\section{Interprofessional Communication (IPC) for Medical Students: A Scoping Review}

\section{Chermaine Bok}

National University Singapore Yong Loo Lin School of Medicine

\section{Cheng Han Ng}

National University Singapore Yong Loo Lin School of Medicine

Jeffery Wei Heng Koh

National University Singapore Yong Loo Lin School of Medicine

Zhi Hao Ong

National University Singapore Yong Loo Lin School of Medicine

Haziratul Zakirah Binte Ghazali

Ngee Ann Polytechnic

\section{Lorraine Hui En Tan}

National University Singapore Yong Loo Lin School of Medicine

Yun Ting Ong

National University Singapore Yong Loo Lin School of Medicine

Clarissa Wei Shuen Cheong

National University Singapore Yong Loo Lin School of Medicine

Annelissa Mien Chew Chin

National University Singapore Yong Loo Lin School of Medicine

Stephen Mason

National University Singapore Yong Loo Lin School of Medicine

Lalit Krishna ( $\sim$ Lalit.Radha-Krishna@liverpool.ac.uk)

University of Liverpool https://orcid.org/0000-0002-7350-8644

\section{Research article}

Keywords: interprofessional communication, medical education, undergraduate medical training, postgraduate medical training, communications skills, medicine

Posted Date: January 3rd, 2020

DOI: https://doi.org/10.21203/rs.2.20046/v1

License: (c) (i) This work is licensed under a Creative Commons Attribution 4.0 International License.

Read Full License 
Page $2 / 35$ 


\section{Abstract}

BACKGROUND Interprofessional communication (IPC) improves patient care, cost efficiency and improves teamwork among healthcare professionals. For medical students IPC training is crucial to navigating complex healthcare practices yet there is little consistency to IPC training. This scoping review looks at IPC training approaches for medical students to improve preparedness for clinical practice.

METHODS Arksey and O'Malley (2005) framework for scoping review was used to guide this review of articles on IPC training for medical students published between 1 January 2000 to 31 December 2017 in PubMed, ScienceDirect, JSTOR, Google Scholar, ERIC, Embase, Scopus, PsycINFO, Mednar and OpenGrey. A 'split approach' that sees concurrent independent use of a directed content analysis and Braun and Clarke's approach to thematic approach was employed by different members of the research team to scrutinize the data.

RESULTS 17,493 titles and abstracts were found, 250 full-text articles were reviewed and 70 full text articles were included. The 'split approach' to analysis forwarded similar themes that corresponded with the different levels of Miller's Pyramid. These were "Knows", "Knows How", "Shows how" and "Does". Each stage involves particular training modalities and context appropriate modes of assessments to measure medical students' competency levels. IPC training was found to be well received, positive, increased students' understanding and practice of communication. Obstacles to IPC training include scheduling constraints, inexperienced and untrained teachers, and initial anxiety and adjustment for students.

CONCLUSIONS This scoping review reveals IPC training to be competency and assessment based, and dependent upon learning objectives and a clear alignment of expectations. Faculty training, a conducive learning environment tailored to the learner, and effective assessment methods at each training stage are crucial to the success of IPC training. Further evaluations are recommended to ensure the translatability of these findings to other medical specialities and other healthcare professions.

\section{Background}

Interprofessional communication (IPC) improves patient care(1-3), cost efficiency(4) and teamwork among healthcare professionals $(5,6)$ leading IPC to be viewed as an essential component of medical education (7) and a core competency for physicians by the Accreditation Council for Graduate Medical Education (ACGME). Furthermore the World Health Organisation Framework for Action on International Education \& Collaborative Practice(8), mandates that healthcare professionals equip themselves for interprofessional practice.

IPC outcomes are defined as effective communication with other health professional students, negotiating and conflict resolution, expressing one's opinions, listening to team members and shared decision making(9). Healthcare professionals are accustomed to developing discipline-specific care plans. With the rise in the need of chronic care in recent times, healthcare teams are confronted with 
patients with multiple chronic conditions who require complex care plan(10). Accordingly, there will be an increasing need for interprofessional communication in chronic care in developing interprofessional shared care plan(11) and to facilitate patient-oriented care(12).

However all too often there is little consistency in IPC training for medical students, leaving them ill equipped for clinical practice (6). Whilst a variety of approaches to increasing awareness of interprofessional teamwork (13) have been employed including use of joint conferences(14), simulationbased interprofessional educational programs (Sim-IPE)(15), faculty development workshops, interprofessional crisis management sessions, interprofessional organising committees and delivery of services (e.g. community health screenings) (7). However, these approaches often lack an evidence-based development of IPC training, assessment methods of students' abilities and the effectiveness of IPC trainings.

The need for this review

In the absence of a consistent approach to communication skills training in medical schools (16), a scoping review of peer-reviewed literature is proposed to collate available information across a variety of settings (17) to map and identify existing gaps in IPC training for medical students. This process must account for communication's socioculturally-sensitive, linguistically dependent, context and user-specific nature $(18,19)$ and variations in medical curricula that also face cost and logistics issues $(20-24)$.

\section{Methods}

The scoping methodology allows the summarisation and circumnavigation of various applicable and actionable information(25) across various pedagogies, assessments, and practice settings employed(26-28) in peer-reviewed and grey literature(20-24). Guided by Preferred Reporting Items for Systematic Reviews and Meta-Analyses Protocols (PRISMA-P) checklist(29) and Levac et al. (2015)(30)'s framework, a 6-stage systematic scoping review protocol was developed for this study $(20,30)$.

Stage 1: Defining the research scope

Guided by local clinicians, educators, researchers, and a medical librarian, the research team identified the primary research question: "what are the characteristics of prevailing IPC programs?". The secondary questions are "what are the development processes, assessment methods, outcomes, and challenges to developing IPC programs?".

These questions were designed based on the population and concept elements of the inclusion and exclusion criteria, which was presented via a PICOS format in Table 1(31). For practical reasons members of the IPC are drawn from a 'small Multi-Disciplinary Team' (MDT) which includes members of healthcare team from the faculties of medicine, nursing, physiotherapy, occupational therapy and social work(32). The protocol was designed with advice and feedback from a panel of experts and the research team.

Table 1: PICOS, inclusion criteria and exclusion criteria applied to database search 


\begin{tabular}{|c|c|c|}
\hline PICOS & Inclusion Criteria & Exclusion Criteria \\
\hline Population & $\begin{array}{l}\text { - Undergraduate medical students from } \\
\text { preclinical and clinical years } \\
\text { - Nurses, and members of allied health } \\
\text { including occupational therapist, } \\
\text { physiotherapist and pharmacist, social } \\
\text { workers }\end{array}$ & $\begin{array}{l}\text { - Complementary medicine, non- } \\
\text { medical specialties (e.g. Veterinary } \\
\text { and Dentistry) and physicians } \\
\text { outside of the Internal Medicine } \\
\text { scope. }\end{array}$ \\
\hline Intervention & $\begin{array}{l}\text { - Pedagogy strategies in educating medical } \\
\text { students about communication within the } \\
\text { healthcare team through face-to-face or real- } \\
\text { time virtual communication approaches }\end{array}$ & $\begin{array}{l}\text { - Assessment tools on } \\
\text { multidisciplinary communication } \\
\text { - Pedagogy strategies in educating } \\
\text { other healthcare providers towards } \\
\text { communicating with physicians }\end{array}$ \\
\hline Comparison & $\begin{array}{l}\text { - Comparison of pedagogy strategies, } \\
\text { evaluation methods, outcomes and } \\
\text { challenges in nurturing interprofessional } \\
\text { communication }\end{array}$ & \\
\hline Outcome & $\begin{array}{l}\text { - Interprofessional communication strategies, } \\
\text { evaluation methods on the effectiveness of } \\
\text { educational practices } \\
\text { - Outcomes and challenges in nurturing } \\
\text { interprofessional communication }\end{array}$ & \\
\hline $\begin{array}{l}\text { Study } \\
\text { design }\end{array}$ & $\begin{array}{l}\text { - Articles in English or translated to English } \\
\text { - All study designs including: } \\
\text { o Mixed methods research, randomized } \\
\text { controlled trials, cohort studies, case-control } \\
\text { studies, cross-sectional studies, and } \\
\text { descriptive papers } \\
\text { o Case reports and series, ideas, editorials, } \\
\text { and perspectives } \\
\text { - Year of Publication: } 1 \text { January } 2000-31 \\
\text { December } 2018 \\
\text { - Databases: PubMed, Embase, CINAHL, } \\
\text { Scopus, PsycINFO, ERIC, JSTOR, and Google } \\
\text { Scholar }\end{array}$ & $\begin{array}{l}\text { - Electronic and print information } \\
\text { not controlled by commercial } \\
\text { publishing }\end{array}$ \\
\hline
\end{tabular}

Stage 2: Identifying relevant research studies

Under the guidance of the librarian from the medical library, local clinicians and educational experts, a search strategy (supplementary 1 ) was formulated by the research team with the following keywords: 'medical students', 'allied health students', 'interprofessional', 'communication' and 'education'.

PubMed, Embase, CINAHL, Scopus, PsycINFO, ERIC, JSTOR, and Google Scholar databases were selected for review, under the guidance of the librarian and education experts. In keeping with Pham et al. (33)'s approach (34) of ensuring a viable and sustainable research process, the research team confined the searches to articles published between 1 January 2000 and 31 December 2018 to ensure that the findings remained relevant, and could accommodate the manpower and time constraints of the research team. All quantitative and qualitative research methodologies that were published in English or was translated to English were included. 
Titles and abstracts from eight databases were screened independently by members of the research team based on the screening criteria as detailed in Stage 2. The articles were exported using EndNote for the removal of duplicates and to generate the full list of relevant titles and abstracts. Searches were conducted independently by the junior reviewers in the research team and the results were subsequently screened by the senior reviewers and mentors through weekly online meetings and discussions. Using the Sandelowski and Barroso (2006)'s(35) 'negotiated consensual validation' approach, the research team decided on the final list of journals to be reviewed. Figure 1 shows a summary of the PRISMA process.

Stage 4: Data characterization and analysis

Led by the notion that communications skills training is a longitudinal process that develops in stages where each stage builds upon the prevailing knowledge of the participants similar to the levels of levels of Miller's Pyramid (36-38) a directed content analysis was adopted(39). The four levels of Miller's Pyramid (36-38) are "knows" which merely requires the learner to be aware of the knowledge and skills, "knows how" that sees the learner apply their knowledge and skills, "shows how" where capacity to apply the knowledge is demonstrated and "does" where the learner is shown to be able to function independently in the clinical setting $(36,38,40)$.

However, some of the review team believed that the decision to adopt directed content analysis to evaluate the data based on Miller's Pyramid (36-38) required further evidencing. As a result, 2 members of the study team carried out independent analyses of the data using a directed content analysis approach $(41,42)$. The 2 members of the study team discussed their findings online and at face-to-face meetings and employed a "negotiated consensual validation" approach to determine final list of themes (43-45).

Concurrently, 3 members of the study team adopted Braun and Clarke's approach to thematic analysis to independently code and analyse all the papers identified in the final list of papers agreed upon in Stage 3. Semantic themes were identified from categorisation of 'detail rich' codes on various aspects of the mentoring process (43). The members of this 3-person study team discussed the themes they identified online and at face-to-face meetings to achieve consensus upon the final list of themes(46).

Both teams then met to discuss their findings from their respective analysis of the data using the directed content analysis approach(39) and Braun and Clarke's approach to thematic analysis. Careful scrutiny of the data suggests significant concurrence in the descriptions of the themes identified using the 'split approach' to analysis.

Stage 5: Results Collation and Summary

Using PRISMA guidelines (Refer to Figure 1), an initial search in 8 databases revealed 17,493 titles and abstracts after removal of duplicates. 250 full-text articles were reviewed and a total of 70 articles were included for thematic analysis in this scoping review. The narratives were written according to the Best 
Evidence Medical Education (BEME) Collaboration guide(47) and the STORIES (Structured approach to the Reporting In healthcare education of Evidence Synthesis) statement.(48)

\section{Results}

The four themes identified were indications were the indications, the stages, the content and the challenges of IPC training.

a. Indications for IPC programmes

The indications for the development of IPC programme are outlined in Table 2. 
Table 2

Indications for an IPC Program

\begin{tabular}{|c|c|c|c|}
\hline $\mathrm{S} / \mathrm{N}$ & Title & Author & Objective of Study \\
\hline 1 & $\begin{array}{l}\text { Promoting Interprofessional } \\
\text { Collaborative Practice Through } \\
\text { Simulation }\end{array}$ & $\begin{array}{l}\text { Alfes, C., et } \\
\text { al }\end{array}$ & $\begin{array}{l}\text { The purpose of this project was to educate } \\
\text { faculty from the university's schools of } \\
\text { nursing, medicine, and physician assistant } \\
\text { (PA) programs on the principles and best } \\
\text { practices of simulation. }\end{array}$ \\
\hline 2 & $\begin{array}{l}\text { Design of a successful } \\
\text { introductory interprofessional } \\
\text { education experience }\end{array}$ & $\begin{array}{l}\text { Helen, M. et } \\
\text { al }\end{array}$ & $\begin{array}{l}\text { This report describes an IPE mini- course } \\
\text { for medical, nursing, and pharmacy } \\
\text { students structured to meet the criteria of } \\
\text { Allport's Contact Hypothesis. }\end{array}$ \\
\hline 3 & $\begin{array}{l}\text { Developing Teamwork Using a } \\
\text { Two-Tiered Debriefing } \\
\text { Approach Clinical Simulation in } \\
\text { Nursing }\end{array}$ & $\begin{array}{l}\text { Andersen, P., } \\
\text { et al }\end{array}$ & $\begin{array}{l}\text { The study aims were as follows: } \\
\text { 1. To determine students' perceptions of } \\
\text { interprofessional learning using immersive } \\
\text { simulation. } \\
\text { 2. To evaluate the impact of a two-tiered } \\
\text { debriefing method on learning about } \\
\text { teamwork during interprofessional } \\
\text { immersive simulation, using a team } \\
\text { performance observational tool (TPOT) } \\
\text { during debriefing. }\end{array}$ \\
\hline 4 & $\begin{array}{l}\text { Interprofessional learning on } \\
\text { polypharmacy }\end{array}$ & $\begin{array}{l}\text { Anderson, E., } \\
\text { et al }\end{array}$ & $\begin{array}{l}\text { This short course enables final-year } \\
\text { students to work with in-patients to } \\
\text { meticulously assess the completeness } \\
\text { and accuracy of their prescriptions. }\end{array}$ \\
\hline 5 & $\begin{array}{l}\text { Attitudes Toward } \\
\text { Communication and } \\
\text { Collaboration After } \\
\text { Participation in a Mock Page } \\
\text { Program: A Pilot of an } \\
\text { Interprofessional Approach to } \\
\text { Surgical Residency Preparation }\end{array}$ & $\begin{array}{l}\text { J. } \\
\text { Arumpanayil, } \\
\text { A., et al }\end{array}$ & $\begin{array}{l}\text { The purpose of this pilot study was to } \\
\text { explore attitudes toward communication } \\
\text { and collaboration among medical and } \\
\text { nursing students, before and after } \\
\text { participation in a mock page program. }\end{array}$ \\
\hline 6 & $\begin{array}{l}\text { Technology-enabled } \\
\text { interprof essional education for } \\
\text { nursing and medical students: } \\
\text { A pilot study }\end{array}$ & $\begin{array}{l}\text { Berg, B., et } \\
\text { al. }\end{array}$ & $\begin{array}{l}\text { This paper reports on a study that } \\
\text { assessed the feasibility of conducting } \\
\text { interprofessional SBAR training with } \\
\text { nursing and medical students using } \\
\text { remote technologies coupled with manikin } \\
\text { simulation. }\end{array}$ \\
\hline 7 & $\begin{array}{l}\text { Evaluation of interprofessional } \\
\text { education: lessons learned } \\
\text { through the development and } \\
\text { implementation of an } \\
\text { interprofessional seminar on } \\
\text { team communication for } \\
\text { undergraduate health care } \\
\text { students in Heidelberg - a } \\
\text { project report }\end{array}$ & $\begin{array}{l}\text { Berger, S., et } \\
\text { al. }\end{array}$ & $\begin{array}{l}\text { This project report describes the } \\
\text { development, "piloting" and evaluation of } \\
\text { an interprofessional seminar on team } \\
\text { communication bringing together medical } \\
\text { students and Interprofessional Health } \\
\text { Care B.Sc. students at the Medical Faculty } \\
\text { of Heidelberg University, Germany. }\end{array}$ \\
\hline
\end{tabular}


S/N Title Author Objective of Study

$8 \quad$ Mock pages are a valid construct for assessment of clinical decision making and interprofessional communication

9 A mixed-methods study of interprofessional learning of resuscitation skills
Boehler, M.

L., et al.

The purpose of this study is to assess standardized mock page cases as a valid construct to assess clinical decision making and interprofessional communication skills.

Bradley, P., et al.

This study aimed to identify the effects of interprofessional resuscitation skills teaching on medical and nursing students' attitudes, leadership, team-working and performance skills.

10 Examining the effects of interprofessional problembased clinical ethics: Findings

Chihchen Chou, F., et al.

We aim to explore how IPE works in from a mixed methods study
Clarke, $\mathrm{H}$. and $\mathrm{M}$. Voss
11 The role of a multidisciplinary student team in the community management of chronic obstructive pulmonary disease learning clinical ethics via PBL setting and how different professions' perspectives influence each other via investigating the learning process and the students' reflection.

To determine whether a community-based, multidisciplinary team consisting of home-based caregivers and supervised students could improve the functional status and quality of life of patients living with chronic obstructive pulmonary disease (COPD) in a low-income, periurban setting in South Africa.

12 Fostering interprofessional communication through case discussions and simulated ward rounds in nursing and medical education: A pilot project
Learning to Overcome

Hierarchical Pressures to

Achieve Safer Patient Care: An

Interprofessional Simulation

for Nursing, Medical, and

14 An inter-professional approach to train and evaluate communication accuracy and completeness during the delivery of nurse-physician student handoffs

15 Interprofessional simulationbased education program: a promising approach for changing stereotypes and improving attitudes toward nurse-physician collaboration
Physician Assistant Students
Wershofen, B., et al.
The aim of this project is to foster communication for medical and nursing students through interprofessional case discussions and simulated ward rounds as a form of training.
Reeves, S. A., et al.
This article describes an interprofessional simulation program to teach structured communication techniques to preprofessional nursing, medical, and physician assistant students.
Maraccini, A., et al.
This study examined the impact of an interprofessional I-PASS training on communication accuracy and completeness during the delivery of nursephysician student handoffs.
Liaw, S. Y., et al.
The purpose of this study was to examine the effects of an interprofessional simulation-based communication education program on medical and nursing students' perception on each other health profession and their attitudes toward nurse-physician collaboration. 


S/N Title Author Objective of Study

16 Teamwork training with nursing and medical students: Does the method matter? Results of an interinstitutional, interdisciplinary collaboration

17 An Interprofessional Workshop for Students to Improve Communication and Collaboration Skills in End-oflife Care

18 COMPARISON of Communication Outcomes in Traditional VERSUS Simulation Strategies in Nursing and Medical Students

The use of simulation and a modified TeamSTEPPS curriculum for medical and nursing student team training simulation

20 "Collaborative-ready" students: Exploring factors that influence collaboration during a longitudinal interprofessional education practice experience

21 Medical school hotline: interprofessional education: future nurses and physicians learning together

\section{A novel interprofessional} shadowing initiative for senior medical students

Rotz, M. and G. Dueñas
Erickson, J. M., et al.

Hobgood, C., et al.
This study was designed and implemented to adapt the TeamSTEPPS content to pre-licensure nursing and medical students, and measure the effectiveness of four educational interventions at teaching this material.

Experiential interprofessional education workshops enhance perceptions about the benefits of teamwork, but further teaching and evaluation methods are needed to maximize the effectiveness.

Reising, D. L., et al.
Robertson,
B., et al.
We describe our adaptation of TeamSTEPPS for our curriculum and its use as an educational intervention for medical and nursing students.

The purpose of this study is to understand interprofessional communication (nursing and medicine) within the context of the educational environment (traditional versus simulation).

The objective of our study was to explore student-reported factors that influence collaboration within our longitudinal IPE experience

Sakai, D. H., et al.

Implemented three collaborative learning experiences for first-year year medical and nursing students.
Shafran, D. M., et al.
This paper presents a unique opportunity to investigate the impact of a novel, multidisciplinary and interprofessional educational experience for senior medical students.

Sick, B., et al.
The student-run free clinic: An ideal site to teach interprofessional education?
This article describes a prospective, observational cohort study of interprofessional attitudes and skills including communication and teamwork skills and attitudes about interprofessional learning, relationships and interactions of student volunteers in a SRFC compared to students who applied and were not accepted to the clinic and to students who never applied to the clinic. 


\begin{tabular}{|c|c|c|c|}
\hline S/N & Title & Author & Objective of Study \\
\hline 24 & $\begin{array}{l}\text { Undergraduate students' } \\
\text { perceptions of and attitudes } \\
\text { toward a simulation-based } \\
\text { interprofessional curriculum: } \\
\text { the KidSIM ATTITUDES } \\
\text { questionnaire }\end{array}$ & $\begin{array}{l}\text { Sigalet, E., et } \\
\text { al. }\end{array}$ & $\begin{array}{l}\text { The purpose of this present study was to } \\
\text { examine the psychometric characteristics } \\
\text { of the KidSIM Attitude Towards Teamwork } \\
\text { in Training Undergoing Designed } \\
\text { Educational Simulation (ATTITUDES) } \\
\text { questionnaire. }\end{array}$ \\
\hline 25 & $\begin{array}{l}\text { Evaluation of an } \\
\text { Interprofessional Education } \\
\text { Communication Skills Initiative }\end{array}$ & $\begin{array}{l}\text { Solomon, P. } \\
\text { and J. Salfi }\end{array}$ & $\begin{array}{l}\text { This study conducted a program } \\
\text { evaluation of an innovative } \\
\text { interprofessional communication skills } \\
\text { initiative which incorporated problem- } \\
\text { based learning, cooperative learning and } \\
\text { standardized patients. }\end{array}$ \\
\hline 26 & $\begin{array}{l}\text { Undergraduate } \\
\text { interprofessional education } \\
\text { using high-fidelity paediatric } \\
\text { simulation }\end{array}$ & $\begin{array}{l}\text { Stewart, M., } \\
\text { et al. }\end{array}$ & $\begin{array}{l}\text { The aim of this study was to develop, } \\
\text { implement and evaluate an } \\
\text { interprofessional undergraduate } \\
\text { programme using high-fidelity paediatric } \\
\text { simulation to learn clinical competencies, } \\
\text { and communication and teamworking } \\
\text { skills. }\end{array}$ \\
\hline 27 & $\begin{array}{l}\text { An interprofessional approach } \\
\text { to improving paediatric } \\
\text { medication safety }\end{array}$ & $\begin{array}{l}\text { Stewart, M., } \\
\text { et al. }\end{array}$ & $\begin{array}{l}\text { The aim of this study was to develop and } \\
\text { evaluate an interprofessional teaching } \\
\text { and learning workshop of paediatric dug } \\
\text { prescribing and administration for medical } \\
\text { and nursing students, which would } \\
\text { facilitate learning of knowledge, core } \\
\text { competencies, communication and team } \\
\text { working skills. In addition, rigorous } \\
\text { evaluation of the workshop could inform } \\
\text { curriculum development. }\end{array}$ \\
\hline 28 & $\begin{array}{l}\text { Child disability case studies: an } \\
\text { interprofessional learning } \\
\text { opportunity for medical } \\
\text { students and paediatric nursing } \\
\text { students }\end{array}$ & $\begin{array}{l}\text { Street, K. N., } \\
\text { et al. }\end{array}$ & $\begin{array}{l}\text { We describe an interprofessional learning } \\
\text { (124) opportunity for pre-qualification } \\
\text { medical and paediatric nursing students } \\
\text { using community- based case studies of } \\
\text { disabled children and their families. }\end{array}$ \\
\hline 29 & $\begin{array}{l}\text { Interprofessional simulation } \\
\text { training improves knowledge } \\
\text { and teamwork in nursing and } \\
\text { medical students during } \\
\text { internal medicine clerkship }\end{array}$ & $\begin{array}{l}\text { M Tofil, N., et } \\
\text { al. }\end{array}$ & $\begin{array}{l}\text { We hypothesized that simulation training } \\
\text { would improve both nursing students' and } \\
\text { medical students' medical knowledge, } \\
\text { communication skills, and understanding } \\
\text { of each profession's role in patient care. }\end{array}$ \\
\hline 30 & $\begin{array}{l}\text { Interprofessional training } \\
\text { enhances collaboration } \\
\text { between nursing and medical } \\
\text { students: A pilot study }\end{array}$ & $\begin{array}{l}\text { Turrentine, } \\
\text { B., et al. }\end{array}$ & $\begin{array}{l}\text { Interprofessional education is } \\
\text { foundational to ensuring that students are } \\
\text { prepared to engage in optimal } \\
\text { collaboration once they enter clinical } \\
\text { practice particularly in the care of complex } \\
\text { geriatric patients undergoing surgery. }\end{array}$ \\
\hline
\end{tabular}


S/N Title Author Objective of Study

31 Analysis of an interprofessional home visit assignment: student perceptions of team-based care, home visits, and

medication-related problems

32 Developing interprofessional communication skills
Vaughn, L.

M., et al.

The objective of this study was to determine the impact of an interprofessional medicine-pharmacy student home visit experience on students' self-assessments of skills and abilities related to team-based care and identification of medication-related problems.

Wagner, J., et al.
This article will describe the development and implementation of a pilot educational teaching/learning simulation exercise designed to promote teamwork and collaboration between medical students and nursing students.
33 Reflections and unprompted observations by healthcare students of an interprofessional shadowing visit

34 Interprofessional education: The student perspective
Wright, A., et

al.

This paper reports work from a Centre for Interprofessional Practice in a higher education institution in the UK that offers four levels of interprofessional learning (124) to all healthcare students.

\section{Lumague,} M., et al.
In an effort to increase interprofessional collaboration, improve communication skills, foster respect and enhance knowledge of the different roles each discipline plays on the health care team, these students met together over a five week period and participated in interprofessional group sessions led by different health care professional leaders from the unit.

\section{An introductory} interprofessional exercise for healthcare students

\section{6}

An Interprofessional Curriculum on Antimicrobial Stewardship Improves Knowledge and Attitudes Toward Appropriate Antimicrobial Use and Collaboration

\section{7}

An interprofessional education pilot program in maternity care: Findings from an exploratory case study of undergraduate students
Macdonnell,

C., et al.
This workshop enabled the students to develop a better understanding of the approaches various health professionals use when caring for patients.

MacDougall, C., et al.
A curriculum on antimicrobial stewardship consisting of independent learning and an interprofessional workshop significantly increased knowledge and attitudes towards collaborative antimicrobial stewardship among preclinical medical and pharmacy students.

Meffe, F., et al. 


S/N Title Author Objective of Study

38 Innovation in learning - An interprofessional approach to improving communication
Mitchell, M., et al.
This pilot project was founded on practicebased learning materials formulated specifically for undergraduate nursing and medical students in the setting of interprofessional small group tutorial.
39 Sustained effects of interprofessional shared learning on student attitudes to communication and team working depend on shared learning opportunities on clinical placement as well as in the classroom
Morison, S. and J. Jenkins
This study compares the attitudes, 1 year after experience of an undergraduate SL programme, of students who had participated in the programme with their peers who had not.
An interprofessional communication skills lab: A pilot project
Salvatori, P., et al.
The new IPE curriculum at McMaster is based on pedagogical principles of competency-based education and small group, problem-based learning
$41 \quad$ Evaluation of a Unique Interprofessional Education Program Involving Medical and Pharmacy Students

42 Integrating Collaborative Interprofessional Simulation into Pre-Licensure Health Care Programs

43

Students' Perceptions on an Interprofessional Ward Round Training - A Qualitative Pilot Study

How can student experience enhance the development of a model of interprofessional clinical skills education in the practice placement setting?

Students' understanding of teamwork and professional roles after interprofessional simulation-a qualitative analysis

$46 \quad$ Medical students' engagement in collaborative communication during an interprofessional standardized patient encounter

\section{J. Nagge, J.,} et al.

This study was designed to evaluate selfreported changes in these domains using a validated pre-post survey instrument.

New, S. N., et al.

The team conference and acute care simulations provided students opportunities to practice interprofessional communication at various levels of care.

Nikendei, C., et al.

The present study aimed to analyse final year students', nurses' as well as physiotherapists' views on a simulation-based interprofessional ward round training.

O'Carroll, V., et al.

Exploring the student experience has assisted in developing relevant and accessible interprofessional learning opportunities within the practice placement setting.

Oxelmark, L., et al.

The present study investigates these concerns in a qualitative analysis of focus group data with undergraduate nursing and medical students after participating in IPSE.

K. Oza, S., et al.

Develop and apply a conceptual framework of ICC. 


S/N Title Author Objective of Study

$47 \quad$ Development and implementation of an interprofessional pharmacotherapy learning experience during an advanced pharmacy practice rotation in primary care

48 A mile in their shoes: interdisciplinary education at the Johns Hopkins University School of Medicine

49 Interprofessional training in the context of clinical practice: goals and students' perceptions on clinical education wards

Ponzer, S., et al.

Pathak, S., et al.

Patel, K., et

al.

The developed IPE program includes the use of case studies and problem-based learning methods to facilitate learning of conditions common in primary care as tools to improve interactions with health professions students.

The specific aim of this article is to describe our experience with creating an interdisciplinary elective for third- and fourth-year medical students at the Johns Hopkins University School of Medicine

This paper describes the context of interprofessional training on clinical education wards (CEWs) and reports students' perceptions of this type of interprofessional and professional training.

50 Evaluating an undergraduate interprofessional simulationbased educational module: communication, teamwork, and confidence performing cardiac resuscitation skills

51 Improving collaboration among medical, nursing and respiratory therapy students through interprofessional simulation

52 Interprofessional education for the quality use of medicines: Designing authentic multimedia learning resources
Luctkar-

Flude, M., et al.
The purpose of this study is to evaluate an innovative simulation-based IP educational module for undergraduate nursing and medical students on cardiac resuscitation skills.

Elizabeth Ann King, A., et al.

Our study suggests that simulated scenarios can help interprofessional collaboration.
Levett-Jones, T., et al.
This paper describes the development of authentic multimedia resources that allow for participative, inter- active and engaging learning experiences based upon sound pedagogical principles.
$53 \quad$ What and how do students learn in an interprofessional student-run clinic? An educational framework for team-based care

54 The impact of an interprofessional problembased learning curriculum of clinical ethics on medical and nursing students' attitudes and ability of interprofessional collaboration: A pilot study
To derive a framework for understanding student learning during team-based care provided in an interprofessional SRC serving underserved patients.
Lin, Y.-C., et al.
Lie, D., et al.

Therefore, we conducted a pilot curricular study to evaluate the curricular impact on students' confidence and attitude of interprofessional collaborative teamwork. 


\begin{tabular}{|c|c|c|c|}
\hline S/N & Title & Author & Objective of Study \\
\hline 55 & $\begin{array}{l}\text { Interprofessional learning } \\
\text { through shadowing: Insights } \\
\text { and lessons learned }\end{array}$ & $\begin{array}{l}\text { V. Kusnoor, } \\
\text { A. and L. A. } \\
\text { Stelljes }\end{array}$ & $\begin{array}{l}\text { This study evaluates (1) how pre-clinical } \\
\text { medical students describe the roles of the } \\
\text { healthcare professionals they shadowed, } \\
\text { and (2) whether shadowing can be used to } \\
\text { introduce medical students to the benefits } \\
\text { of interprofessional collaboration, and if } \\
\text { so, in what ways. }\end{array}$ \\
\hline 56 & $\begin{array}{l}\text { Interprofessional student-led } \\
\text { clinics: An innovative approach } \\
\text { to the support of older people } \\
\text { in the community }\end{array}$ & Kent, F., et al. & $\begin{array}{l}\text { Undergraduate students, working in mixed } \\
\text { professional teams, are able to deliver a } \\
\text { useful additional health promotion service } \\
\text { to older people. }\end{array}$ \\
\hline 57 & $\begin{array}{l}\text { Interprofessional clinical } \\
\text { training for undergraduate } \\
\text { students in an emergency } \\
\text { department setting }\end{array}$ & $\begin{array}{l}\text { Ericson, A., et } \\
\text { al. }\end{array}$ & $\begin{array}{l}\text { We conclude that training at an } \\
\text { emergency department can provide } \\
\text { excellent opportunities for } \\
\text { interprofessional team training for } \\
\text { undergraduate students. }\end{array}$ \\
\hline 58 & $\begin{array}{l}\text { Indonesian students' } \\
\text { participation in an } \\
\text { interprofessional learning } \\
\text { workshop }\end{array}$ & $\begin{array}{l}\text { Ernawati, D., } \\
\text { et al. }\end{array}$ & $\begin{array}{l}\text { This study found that learning with other } \\
\text { health students through an IPE workshop } \\
\text { improved medical, nursing and pharmacy } \\
\text { students' attitudes towards the } \\
\text { importance of shared learning, teamwork } \\
\text { and communication in healthcare service. }\end{array}$ \\
\hline 59 & $\begin{array}{l}\text { Nursing and medical students } \\
\text { teaming up: Results of an } \\
\text { interprofessional project }\end{array}$ & $\begin{array}{l}\text { Feather, R., et } \\
\text { al. }\end{array}$ & \\
\hline 60 & $\begin{array}{l}\text { Simulating a patient's fall as a } \\
\text { means to improve routine } \\
\text { communication: Joint training } \\
\text { for nursing and fifth-year } \\
\text { medical students }\end{array}$ & $\begin{array}{l}\text { Flentje, M., et } \\
\text { al. }\end{array}$ & $\begin{array}{l}\text { To improve interprofessional } \\
\text { communication and task management, a } \\
\text { simulation-based emergency training } \\
\text { session for nursing students and fifth-year } \\
\text { medical students was developed at the } \\
\text { KRH Klinikum Nordstadt in Hanover, } \\
\text { Germany. }\end{array}$ \\
\hline 61 & $\begin{array}{l}\text { Effects of interprofessional } \\
\text { education on patient perceived } \\
\text { quality of care }\end{array}$ & $\begin{array}{l}\text { Hallin, K., et } \\
\text { al. }\end{array}$ & $\begin{array}{l}\text { To assess the patients' perceptions of } \\
\text { collaborative and communicative aspects } \\
\text { of care when treated by interprofessional } \\
\text { student teams as compared to usual care. }\end{array}$ \\
\hline 62 & $\begin{array}{l}\text { Active interprofessional } \\
\text { education in a patient based } \\
\text { setting increases perceived } \\
\text { collaborative and professional } \\
\text { competence }\end{array}$ & $\begin{array}{l}\text { Hallin, K., et } \\
\text { al. }\end{array}$ & $\begin{array}{l}\text { To evaluate whether students perceived } \\
\text { that they had achieved interprofessional } \\
\text { competence after participating in clinical } \\
\text { teamwork training. }\end{array}$ \\
\hline 63 & $\begin{array}{l}\text { Interprofessional working in } \\
\text { acute care }\end{array}$ & $\begin{array}{l}\text { Holland, C., } \\
\text { et al. }\end{array}$ & $\begin{array}{l}\text { This paper describes the development and } \\
\text { implementation of an interprofessional } \\
\text { (IP) module for pre-qualification medical, } \\
\text { nursing and physiotherapy students. }\end{array}$ \\
\hline
\end{tabular}




\begin{tabular}{|c|c|c|c|}
\hline S/N & Title & Author & Objective of Study \\
\hline 64 & $\begin{array}{l}\text { Development of an } \\
\text { interprofessional educational } \\
\text { module on infection control } \\
\text { using high-fidelity patient } \\
\text { simulation }\end{array}$ & $\begin{array}{l}\text { Luctkar- } \\
\text { Flude, M., et } \\
\text { al. }\end{array}$ & $\begin{array}{l}\text { This mixed methods study evaluated an } \\
\text { interprofessional education infection } \\
\text { control module as part of a larger action } \\
\text { research project aimed at developing } \\
\text { interprofessional health education using } \\
\text { simulation }\end{array}$ \\
\hline 65 & $\begin{array}{l}\text { Developing a Foundation for } \\
\text { Interprofessional Education } \\
\text { Within Nursing and Medical } \\
\text { Curricula }\end{array}$ & $\begin{array}{l}\text { Leann } \\
\text { Horsley, T., et } \\
\text { al. }\end{array}$ & $\begin{array}{l}\text { This article describes how a nursing and a } \\
\text { medical school collaborated to } \\
\text { systematically integrate IPE simulations } \\
\text { into the curricula so that every graduate } \\
\text { from the respective schools received } \\
\text { TeamSTEPPS }{ }^{\circledR} \text { education and } \\
\text { participated in a standardized IPE } \\
\text { simulation experience }\end{array}$ \\
\hline 66 & $\begin{array}{l}\text { Medical student perceptions of } \\
\text { an initial collaborative } \\
\text { immersion experience }\end{array}$ & $\begin{array}{l}\text { House, J., et } \\
\text { al. }\end{array}$ & $\begin{array}{l}\text { This article describes the development of } \\
\text { and early outcomes for the initial clinical } \\
\text { experience (ICE) course, an innovative } \\
\text { collaborative model and a core } \\
\text { component of the University of Michigan } \\
\text { Medical School's redesigned curriculum. }\end{array}$ \\
\hline 67 & $\begin{array}{l}\text { Decline in medical students' } \\
\text { attitudes to interprofessional } \\
\text { learning and patient- } \\
\text { centredness }\end{array}$ & $\begin{array}{l}\text { Hudson J., et } \\
\text { al }\end{array}$ & $\begin{array}{l}\text { This study explores graduate-entry } \\
\text { medical students' attitudes to IPL and } \\
\text { patient-centred care, on programme entry } \\
\text { and after an early interdisciplinary clinical } \\
\text { experience (ICE). }\end{array}$ \\
\hline 68 & $\begin{array}{l}\text { Students' approaches to } \\
\text { learning in clinical } \\
\text { interprofessional context }\end{array}$ & $\begin{array}{l}\text { Ponzer, S., et } \\
\text { al. }\end{array}$ & $\begin{array}{l}\text { We investigated health care students' } \\
\text { evaluations of interprofessional clinical } \\
\text { training in relation to their study } \\
\text { orientations. }\end{array}$ \\
\hline 69 & $\begin{array}{l}\text { Implementing a nurse- } \\
\text { shadowing program for first- } \\
\text { year medical students to } \\
\text { improve interprofessional } \\
\text { collaborations on health care } \\
\text { teams }\end{array}$ & Jain, A., et al. & $\begin{array}{l}\text { We then investigated the impact of this } \\
\text { intervention on medical students' } \\
\text { knowledge of the roles of nurses as well } \\
\text { as their attitudes toward and } \\
\text { understanding of the contributions of } \\
\text { nurses to the health care team. }\end{array}$ \\
\hline 70 & $\begin{array}{l}\text { Examining participant } \\
\text { perceptions of an } \\
\text { interprofessional simulation- } \\
\text { based trauma team training for } \\
\text { medical and nursing students }\end{array}$ & $\begin{array}{l}\text { Jakobsen, R., } \\
\text { et al. }\end{array}$ & $\begin{array}{l}\text { The aim of this paper is to describe the } \\
\text { adaptation of an interprofessional } \\
\text { simulation course in an undergraduate } \\
\text { setting and to report participants' } \\
\text { experiences with the course and students' } \\
\text { learning outcomes. }\end{array}$ \\
\hline 71 & $\begin{array}{l}\text { First Contact: interprofessional } \\
\text { education based on medical } \\
\text { students' experiences from } \\
\text { their nursing internship }\end{array}$ & $\begin{array}{l}\text { Eich-Krohm, } \\
\text { A., et al. }\end{array}$ & $\begin{array}{l}\text { To meet the demographic challenges } \\
\text { ahead it is important to emphasize inter- } \\
\text { professional education in the study of } \\
\text { medicine and better prepare fu- ture } \\
\text { physicians for interprofessional } \\
\text { collaboration. }\end{array}$ \\
\hline
\end{tabular}




\begin{tabular}{|llll|}
\hline S/N & Title & Author & Objective of Study \\
\hline 72 & $\begin{array}{l}\text { Interprofessional education } \\
\text { using simulation of an } \\
\text { overnight inpatient ward shift }\end{array}$ & $\begin{array}{l}\text { M. Joyal, K., } \\
\text { et al. }\end{array}$ & $\begin{array}{l}\text { The purpose of this study was to } \\
\text { investigate the interprofessional } \\
\text { knowledge, skills and attitudes the } \\
\text { students learn from this experience. }\end{array}$ \\
73 & $\begin{array}{l}\text { A Human Factors Curriculum } \\
\text { for Surgical Clerkship Students }\end{array}$ & $\begin{array}{l}\text { Cahan, M., et } \\
\text { al. }\end{array}$ & $\begin{array}{l}\text { Early introduction of a full-day human } \\
\text { factors training experience into the } \\
\text { surgical clerkship curriculum will teach } \\
\text { effective communication skills and } \\
\text { strategies to gain professional } \\
\text { satisfaction from a career in surgery. }\end{array}$ \\
\hline
\end{tabular}

b. Stages of IPC Training

IPC training is conducted through various modalities such as didactic lectures, tutorials, simulations, shadowing and clinical experiences. The choice of modalities was determined by the training context and modes of assessments. The methods used to train and assess students can be grouped using the Miller's Pyramid(36, 38, 49, 50). Miller's Pyramid provides a framework for assessing clinical competence in medical education and is useful in aligning learning outcomes with expectations of the students' abilities at 4 stages: "Knows", "Knows How", "Shows how" and "Does".

Each stage is prefaced by description of the stage and includes discussions about the assessment tools and the outcomes of each stage.

Stage 1: Knows

Forming the base of the pyramid, "Knows" lays the foundation for building clinical competency. IPC training in this stage pivot around formal programmes including online courses, participating in a healthcare day (51), didactic lectures and workshops (52-59), seminars, and conferences about IPC (6063). Workshops and tutorials were used to provide a platform for students to engage in problem based discussions $(57,58,61,64-73)$ and learn communications skills $(64,74,75)$.

Assessment Tools

Students were assessed via self-reported qualitative and quantitative surveys $(2,15,51-53,59,60,62,64$, $65,68,70,73,76-94)$, focused group discussions $(80,95,96)$ and semi-structured interviews $(56,64,76$, 97-100).

Outcomes

Outcomes were positive, with students reporting an increase in understanding of IPC $(2,52,60,76-79$, $92-94,99,101,102)$.

Stage 2: Knows How 
To achieve the "Knows How" level of competence, students have to be cognizant of how to apply the concepts learnt in a variety of conditions including clinical and non-clinical scenarios. Clinical scenarios include cardiac resuscitations $(56,64,75,89)$, handoff(103), mock pages $(104,105)$, interactions with simulated patients $(52,53,63,100,103)$ and manikins $(58,79,81,83,106-109)$, communication with a senior clinician(101), simulated ward rounds $(15,54,55,84,110,111)$, simulated family meetings(59), roleplay(72, 112), paediatric clinical simulation(82), Objective Structured Clinical Exam simulation(113), laboratory sessions(74). Non-clinical scenarios include family conflicts and culture sensitivity incorporated into simulations. To aid in the experience of the learner, lectures and viewing of videos usually preceded simulations $(52,104)$. Debriefings were conducted to consolidate, reflect and explore learning points and address challenges brought up by the students $(52,63,84,108,111,114)$.

Assessment Tools

Students were assessed by self-reported qualitative and quantitative surveys, focused group discussions as well as semi-structured interviews.

\section{Outcomes}

Students reported self-perceived improvement in IPC and the increased ability to adapt different communication styles in future practices $(2,15,51,52,55,59,65,69,75,77,78,80,81,83,86,101,106$, $115,116)$.

\section{Stage 3: Shows How}

The third stage of the Miller's pyramid comprises the "Shows How" level, where students are required to demonstrate the application of knowledge in their clinical performance. IPC training is conducted during clinical attachments $(57,77,88,91,102,115,117)$. Medical students also shadowed members of the healthcare team, observing interactions between healthcare professionals $(80,116,118-120)$.

\section{Assessment Tools}

Assessment of students' communication skills was carried out by faculty members $(64,71,73,85,103$, $106)$ and simulated patients $(58,67,71)$, supplemented with feedback from simulated patients during IPC and team building exercises(67). A post-training analysis of verbal units of exchange during handoffs quantified improvements in communication skills(103).

\section{Outcomes}

Results reflected a transfer of IPC training skills to clinical practice $(58,67,71)$. Feedback from simulation assessments illustrated improvement of communication skills (103) and positive results in IPC and team building(67).

Stage 4: Does 
At the apex of the pyramid, the "Does" level focuses on the behaviour of the students in the clinical setting. IPC training is facilitated via longitudinal experiential learning in clinics and wards $(88,91,93$, 117), home visits $(86,99,121)$, student-led clinics $(90,96-98)$ and motivational interviews(71) with patient involvement, which provide repeated opportunities for students in IPC teams to share knowledge and collaborate in the routine care of patients. Home visits provided opportunities for teams to conduct collaborative medical interviews, explore patient difficulties, and manage challenging situations $(86,99)$.

Assessment Tools

Students were assessed using patient feedback in the form of a questionnaire(90, 93). To assess longer term impact of IPC training, interviews and self-reported questionnaires were carried out months after conclusion of IPC training to assess students' application and retention of concepts in routine clinical performance(62).

\section{Outcomes}

Patients assessing students reported that students appeared to be more knowledgeable, and that staff involved in IPC training thoroughly considered their social situation when preparing for their discharge and are more likely to provide information regarding possible home assistance(93). Students demonstrated retention of communication techniques(101) and attempts to achieve IPC in future practices were recorded $(95,101)$. However, there was a decrease in scores for collaboration 3-4 months post-training (64).

c. Content of IPC Programmes

Table 3 describes the list of topics in IPC programmes.

Table 3: List of topics for IPC Programmes and methods of training 
Workshops and Discussion

Case learning on medical safety

Reflecting on videos where nurse and senior resident had different degrees of anxiety about a postoperative patient

Respiratory Distress

Antimicrobial Stewardship

Ethical Case Discussions

Helping patient's sister make a decision about goals of care for patient

Interviews

Interview a nurse and a physician about their experiences with IPC

Simulations

Infection Control

Manikin: Anaphylaxis Chronic obstructive pulmonary disease (COPD), Early sepsis,

Acute coronary syndrome and Acute stroke

Manikin: Respiratory Distress

Manikin: Cardiac Resuscitation

Manikin: Management of emergency situations

Manikin: Paediatric Simulation

Simulated Patient Meeting: Developing care plan for diabetic patient

Simulated Patient Meeting: standardized patients exhibiting mild dementia, Parkinson's disease and frailty

Simulated Patient: inpatient and outpatient scenario that required interaction of at least three different health professionals.

Communication challenges involved dealing with cultural issues, a difficult patient, and family conflict.

Ward Rounds: Designed based on model developed by Nikendei et al.

Ward Rounds: Simulated emergency department room for patients being admitted to the inpatient internal medicine service

Ward Rounds: Communicating results of case discussion to patients

Ward-based Workshops: Paediatric Medication Safety

Course-based assessment 


\section{Topics}

Studies

Experiential Learning with real patients

Home Visits: Develop holistic view of implications of childhood impairment by visiting a child with disabilities

Home Visits: Patients with medication related problems

Home Visits: For management of Chronic Obstructive Pulmonary Disease (COPD)

Ward Training with wide variety of orthopaedic diagnoses

Ward Training: Polypharmacy

Shadowing: Maternity Care

Shadowing: Various Healthcare Professionals $(80,87,118$, 119)

Shadowing: Nurses

Topics

Studies

Workshops and Discussion

$(59-61,65-$ $68,73)$

Interviews

Simulations

Infection Control

Manikins

$(75,82,83,89$, $107,111)$

Simulated Patients

$(85,100,104)$

Ward Rounds

$(54,78,84)$

Ward-based Workshop

Course-based Assessment

Experiential Learning with Real Patients

Home Visits

$(86,99,121)$

Ward Training

$(77,93)$

Shadowing

$(80,87,95$, 118-120)

d. Challenges of IPC training 
Scheduling conflicts, difficulties in preparing effective and appropriate programs, obstacles in recruiting (106) and training $(78)$ teachers $(61,88)$ and students $(53)$ for IPC training, were the most common problem facing IPC training $(62,83,86,108)$.

Stage 6: Consultations with key stakeholders

Consultations on the results of the scoping review were held with local educators, clinicians and researchers well versed in IPC training. There was a general consensus on the results of this review with recognition of various teaching strategies and assessment methods, and the need for further research on the impact of IPC training on inter-professional collaborations and in the design of comprehensive and longitudinal training and assessments programs of students and trainers that also considered the influence of external factors, the environment and contextual and local factors.

\section{Discussion}

In addressing the primary research question, this scoping review reveals a diverse training and assessment environment with individualised training content and methods being adopted across IPC training. Whilst it is evident this is in part due to diverse understanding and differing concepts of IPC, differences in settings and contextual factors closer scrutiny of these findings suggests the presence of individual often independent programs focused upon enhancing knowledge and skills in different aspects of IPC training. It is only when these 'snap shots' are considered holistically and within a training spectrum such as that explicated by Miller's Pyramid that the true nature of IPC becomes clear(36, 38, $50)$.

Seen as part of a wider training program, the first two stages of "Knows" and "Knows How" can be seen to focus on the cognitive abilities of students in understanding and developing IPC skills, while the third and fourth stages, "Shows How" and "Does" emphasise on behavioural changes of students during training and as future clinicians. The grouping of IPC training according to the Miller's Pyramid helps make sense of the dissonant practices and serves as a guide for medical educators to match the content, assessment and learning objectives with the appropriate IPC stage. Awareness of the proposed stage of training will help determine the content, the training method, the learning objectives and assessment methods to be used.

Envisaging IPC training as stages defined by Miller's Pyramid sees IPC conducted in a step-wise manner where each stage lays the foundation for the subsequent stage. This underscores the importance of outlining clear learning objectives and outcomes at every stage of IPC training, to correspond to various competency levels. This is emphasised in the presence of IPC trainers from different specialities who will also require alignment of expectations and establishing codes of conduct for structuring of the IPC programme. Furthermore, these trainers need to be trained to ensure that IPC training is conducted in an open and non-intimidating manner, and guided in facilitating a conducive and respectful learning environment $(75,83)$. Trainers must also be skilled in providing specific feedback, and to reinforce positive communication and teamwork(53). This must be guided by individualised context appropriate 
assessment processes that help trainers recognise the needs of the learner, personalise their training to best fit the learner's needs, and inform the training process for the next stage of training are vital to the success of IPC. This highly tailored training process pivots upon versatility within the IPC program, with room for remediation of trainees.

There is however little data on structuring, supporting and policing this evolving program.

\section{Limitations}

While it is reassuring that there is consistency in IPC training programs, there are a number of limitations to be addressed.

Perhaps most striking about the methodology employed is use of directed content analysis that was guided by Miller's Pyramid. It was in anticipation of concerns about the validity of use of a directed content analysis based on a relatively unique interpretation of the data and also to address researcher reflexivity that the 'split approach' was adopted. Use of Braun and Clarke (2006)'s approach to thematic analysis served as a means of confirming the evidence, a form of triangulation and a method of enhancing the validity of the findings(122). Concurrently employ of 'negotiated consensual validation'(46) served as a means of peer debrief which may be argued further enhances the validity of the findings.

Two, drawing conclusions from a small pool of papers which were limited to articles published or translated to the English languagecan be problematic particularly when most are North American and European-centric. This may limit the applicability of the findings in wider healthcare settings.

Three, there is much to be clarified about the IPC training and assessment processes. This situation is not helped by a lack of holistic and longitudinal assessments and the continued reliance upon assessment tools still rooted in "Cartesian reductionism and Newtonian principles of linearity"(123) and fail to consider the evolving nature of the IPC training process and training environment $(51,58,64)$

Four, despite our independent efforts to carry out our searches and independent efforts to verify our searches and consolidate our findings there may still be important articles that have been omitted.

\section{Conclusion}

The presence of different trainers and many different trainees underlines the need for better understanding of the relational and educational dynamics within IPC interactions. This will inform program developers and administrators about design, oversight, support and policing of IPC programs and guide the establishment of the codes of conduct and practice standards that will confine personalisation of the IPC program to prevent misuse of this process and delineate appropriate expectations and competency levels for the various learners from backgrounds and levels of training. 
Further studies on the long-term impact of IPC training are also required to guide design and structuring of the assessment programs and to inform the trainer and trainee education programs.

\section{List Of Abbreviations}

Interprofessional collaboration (IPC); Interprofessional education (IPE); Multi-Disciplinary Team (MDT); Preferred Reporting Items for Systematic Reviews and Meta-Analyses (PRISMA)

\section{Declarations}

\section{Ethics Approval and Consent to Participate}

IRB approval was not required

\section{Consent for publication}

Not applicable

\section{Availability of data and materials}

All data generated or analysed during this study are included in this published article under Table 2: Indications for an IPE Programme.

\section{Competing interests}

The authors declare that they have no competing interests.

\section{Funding}

None. This work was carried out as part of the Palliative Medicine Initiative run by the Division of Supportive and Palliative Care at the National Cancer Centre Singapore.

\section{Authors' contribution}

$\mathrm{CB}, \mathrm{NCH}, \mathrm{LKRK}, \mathrm{JKWH}$ and HZBG has conducted the initial database search and carried out the directed content analysis of the data.

LKRK, LHET and OYT carried out the secondary searches and analysis using the Braun and Clarke's approach to thematic analysis.

LKRK, LHET, CB, NCH, JKWH, OYT, HZBG and CCWS reviewed the findings and the conclusions. CB wrote the initial manuscript which critically revised by LKRK, SM, LHET, OYT and CCWS. All authors read and approved the final manuscript.

\section{Acknowledgments}


This paper is dedicated to the late Dr. S. Radha Krishna, whose advice and insights were critical to the conceptualization of this review.

The authors would also like to thank the anonymous reviewers whose guidance and feedback greatly enhanced this manuscript.

\section{References}

1. Barnsteiner JH, Disch Jm Fau - Hall L, Hall L Fau - Mayer D, Mayer D Fau - Moore SM, Moore SM. Promoting interprofessional education. (0029-6554 (Print)).

2. Reeves S, Lewin S, Espin S, Zwarenstein M. Interprofessional Teamwork in Health and Social Care2010.

3. Philpot C, Tolson D, Morley J. Advanced Practice Nurses and Attending Physicians: A Collaboration to Improve Quality of Care in the Nursing Home. Journal of the American Medical Directors Association. 2011;12:161-5.

4. Zwarenstein M. Interprofessional education: effects on professional practice and health care outcomes (Review). 2008.

5. Shamian J, El-Jardali F. Healthy Workplaces for Health Workers in Canada: Knowledge Transfer and Uptake in Policy and Practice. HealthcarePapers. 2007;7 Spec No:6-25.

6. Foronda C, MacWilliams B, McArthur E. Interprofessional communication in healthcare: An integrative review. (1873-5223 (Electronic)).

7. Jacobs JL, Samarasekera Dd Fau - Chui WK, Chui Wk Fau - Chan SY, Chan Sy Fau - Wong LL, Wong LI Fau - Liaw SY, Liaw Sy Fau - Tan ML, et al. Building a successful platform for interprofessional education for health professions in an Asian university. (1466-187X (Electronic)).

8. Framework for action on interprofessional education and collaborative practice [press release]. Health Professions Networks Nursing \& Midwifery Human Resources for Health2010.

9. Thistlethwaite J, Moran M. Learning outcomes for interprofessional education (IPE): Literature review and synthesis. (1469-9567 (Electronic)).

10. Wijlhuizen GJ, Perenboom Rj Fau - Garre FG, Garre Fg Fau - Heerkens YF, Heerkens Yf Fau - van Meeteren N, van Meeteren N. Impact of multimorbidity on functioning: evaluating the ICF Core Set approach in an empirical study of people with rheumatic diseases. (1651-2081 (Electronic)).

11. Bodenheimer T, Chen E Fau - Bennett HD, Bennett HD. Confronting the growing burden of chronic disease: can the U.S. health care workforce do the job? (1544-5208 (Electronic)).

12. Van Royen P, Rees Ce Fau - Groenewegen P, Groenewegen P. Patient-centred interprofessional collaboration in primary care: challenges for clinical, educational and health services research. An EGPRN keynote paper. (1751-1402 (Electronic)).

13. Ahmad MI, Chan Sw Fau - Wong LL, Wong LI Fau - Tan ML, Tan MI Fau - Liaw SY, Liaw SY. Are firstyear healthcare undergraduates at an Asian university ready for interprofessional education? (1469- 
9567 (Electronic)).

14. Chua AZ, Lo DY, Ho WH, Koh YQ, Lim DS, Tam JK, et al. The effectiveness of a shared conference experience in improving undergraduate medical and nursing students' attitudes towards interprofessional education in an Asian country: a before and after study. (1472-6920 (Electronic)).

15. Liaw SY, Zhou WT, Lau TC, Siau C, Chan SW. An interprofessional communication training using simulation to enhance safe care for a deteriorating patient. Nurse Educ Today. 2014;34(2):259-64.

16. Gude T, Vaglum P, Anvik T, Baerheim A, Fasmer OB, Grimstad H, et al. Do physicians improve their communication skills between finishing medical school and completing internship? A nationwide prospective observational cohort study. Patient Educ Couns. 2009;76(2):207-12.

17. Mauksch L, Farber S, Greer H. Design, dissemination, and evaluation of an advanced communication elective at seven U.S. medical schools. Academic Medicine. 2013;88(6):843-51.

18. Horsley T. Tips for Improving the Writing and Reporting Quality of Systematic, Scoping, and Narrative Reviews. J Contin Educ Health Prof. 2019;39(1):54-7.

19. Munn Z, Peters MDJ, Stern C, Tufanaru C, McArthur A, Aromataris E. Systematic review or scoping review? Guidance for authors when choosing between a systematic or scoping review approach. BMC Medical Research Methodology. 2018;18(1):143.

20. Arksey H, O'Malley L. Scoping studies: towards a methodological framework. International Journal of Social Research Methodology. 2005;8(1):19-32.

21. Grant MJ, Booth A. A typology of reviews: an analysis of 14 review types and associated methodologies. Health Information \& Libraries Journal. 2009;26(2):91-108.

22. Lorenzetti DL, Powelson SE. A scoping review of mentoring programs for academic librarians. The Journal of Academic Librarianship. 2015;41(2):186-96.

23. Mays N, Roberts E, Popay J. Synthesising research evidence. Studying the organization and delivery of health services: research methods. Edited by: Fulop N, Allen P, Clarke A, Black N. 2001. London: Routledge; 2001.

24. Thomas A, Menon A, Boruff J, Rodriguez AM, Ahmed S. Applications of social constructivist learning theories in knowledge translation for healthcare professionals: a scoping review. Implementation Science. 2014;9(1):54.

25. Du Mont J, Macdonald S, Kosa D, Elliot S, Spencer C, Yaffe M. Development of a comprehensive hospital-based elder abuse intervention: an initial systematic scoping review. PloS one. 2015;10(5):e0125105.

26. Blondon KS, Maitre F, Muller-Juge V, Bochatay N, Cullati S, Hudelson P, et al. Interprofessional collaborative reasoning by residents and nurses in internal medicine: Evidence from a simulation study. 2017(1466-187X (Electronic)).

27. Bays AM, Engelberg Ra Fau - Back AL, Back Al Fau - Ford DW, Ford Dw Fau - Downey L, Downey L Fau - Shannon SE, Shannon Se Fau - Doorenbos AZ, et al. Interprofessional communication skills training for serious illness: evaluation of a small-group, simulated patient intervention. 2014(15577740 (Electronic)). 
28. Zabar S, Adams J, Kurland S, Shaker-Brown A, Porter B, Horlick M, et al. Charting a Key Competency Domain: Understanding Resident Physician Interprofessional Collaboration (IPC) Skills. 2016(15251497 (Electronic)).

29. Osama T, Brindley D, Majeed A, Murray KA, Shah H, Toumazos M, et al. Teaching the relationship between health and climate change: a systematic scoping review protocol. BMJ open. 2018;8(5):e020330.

30. Levac D, Colquhoun H, O'Brien KK. Scoping studies: advancing the methodology. Implement Sci. 2010;5:69.

31. Peters M, Godfrey C, Mclnerney P, Soares C, Khalil H, Parker D. Methodology for JBI Scoping Reviews. 2015. p. 1-24.

32. Lalit KRK. Continous Deep Palliative Sedation: An Ethical Analysis National University of Singapore: National University of Singapore; 2013.

33. Irct20140518017736N. The effectiveness of family-centered empowerment, collaborative care model and motivational interviewing techniques on blood sugar control and eating behaviors. http://wwwwhoint/trialsearch/Trial2aspx?TrialID=IRCT20140518017736N10. 2018.

34. Pham MT, Rajić A, Greig JD, Sargeant JM, Papadopoulos A, McEwen SA. A scoping review of scoping reviews: advancing the approach and enhancing the consistency. Research synthesis methods. 2014;5(4):371-85.

35. Sandelowski M BJ. Handbook for synthesizing qualitative research.: Springer Publishing Complany; 2006.

36. Cruess RL, Cruess SR, Steinert Y. Amending Miller's Pyramid to Include Professional Identity Formation. Academic medicine : journal of the Association of American Medical Colleges. 2016;91(2):180-5.

37. Al-Eraky M, Marei H. A fresh look at Miller's pyramid: assessment at the 'Is' and 'Do' levels. Medical Education. 2016;50(12):1253-7.

38. Miller GE. The assessment of clinical skills/competence/performance. Acad Med. 1990;65(9 Suppl):S63-7.

39. Assarroudi, A., Heshmati Nabavi, F., Armat, M. R., Ebadi, A., \& Vaismoradi, M. (2018). Directed qualitative content analysis: the description and elaboration of its underpinning methods and data analysis process. Journal of Research in Nursing, 23(1), 42-55.

40. Mehay R, Burns R. "Miller's Pyramid of Clinical Competence" The Essential Handbook for GP Training and Education (chapter 29: Assessment and Competence, p414). ed2009 2009.

41. Krishna L, Toh YP, Mason S, Kanesvaran R. Mentoring stages: A study of undergraduate mentoring in palliative medicine in Singapore. PloS one. 2019;14(4):e0214643.

42. Hsieh HF, Shannon SE. Three approaches to qualitative content analysis. Qual Health Res. 2005;15(9):1277-88. 
43. Braun V, Clarke V. Using thematic analysis in psychology. . Qualitative Research in Psychology 2006;3(2):77-101.

44. Gordon M, Gibbs T. STORIES statement: publication standards for healthcare education evidence synthesis. BMC Med. 2014;12:143.

45. Sambunjak D, Straus SE, Marusic A. A systematic review of qualitative research on the meaning and characteristics of mentoring in academic medicine. J Gen Intern Med. 2010;25(1):72-8.

46. Sandelowski M, Barroso J. Handbook for synthesizing qualitative research: Springer Publishing Company; 2006.

47. Haig A, Dozier M. BEME Guide no 3: systematic searching for evidence in medical education-Part 1: Sources of information. Med Teach. 2003;25(4):352-63.

48. Frei E, Stamm M, Buddeberg-Fischer B. Mentoring programs for medical students--a review of the PubMed literature 2000-2008. BMC Med Educ. 2010;10:32.

49. Ramani S, Leinster S. AMEE Guide No. 34: Teaching in the clinical environment. Medical teacher. 2008;30:347-64.

50. Mehay R BR. Miller's Pyramid of Clinical Competence2009.

51. J. Nagge J, F. Lee-Poy M, L. Richard C. Evaluation of a Unique Interprofessional Education Program Involving Medical and Pharmacy Students. American Journal of Pharmaceutical Education. 2017;81:ajpe6140.

52. Alfes C, Rutherford-Hemming T, M. Schroeder-Jenkinson C, Booth Lord C, Zimmermann E. Promoting Interprofessional Collaborative Practice Through Simulation. Nursing Education Perspectives. 2018;39:1.

53. Solomon P, Salfi J. Evaluation of an interprofessional education communication skills initiative. Education for health (Abingdon, England). 2011;24:616.

54. Nikendei C, Huhn D, Pittius G, Trost Y, Bugaj T, Koechel A, et al. Students' Perceptions on an Interprofessional Ward Round Training - A Qualitative Pilot Study. GMS J Med Educ. 2016;33:Doc14.

55. M. Joyal K, Katz C, Harder B, Dean H. Interprofessional education using simulation of an overnight inpatient ward shift. Journal of Interprofessional Care. 2014;29.

56. Flentje M, Müßel T, Henzel B, Jantzen J-P. Simulating a patient's fall as a means to improve routine communication: Joint training for nursing and fifth-year medical students. GMS J Med Educ. 2016;33:Doc 18.

57. Lumague M, Morgan A, Mak D, Hanna M, Kwong J, Cameron C, et al. Interprofessional education: The student perspective. Journal of interprofessional care. 2006;20:246-53.

58. Hobgood C, Sherwood G, Frush K, Hollar D, Maynard L, Foster B, et al. Teamwork training with nursing and medical students: does the method matter? Results of an interinstitutional, interdisciplinary collaboration. Qual Saf Health Care. 2010;19(6):e25.

59. Erickson JM, Blackhall L, Brashers V, Varhegyi N. An interprofessional workshop for students to improve communication and collaboration skills in end-of-life care. Am J Hosp Palliat Care. 
2015;32(8):876-80.

60. Ernawati D, Lee Y, Hughes J. Indonesian students' participation in an interprofessional learning workshop. Journal of Interprofessional Care. 2014;29.

61. Cahan M, Larkin A, Starr S, Wellman S, Haley H-L, Sullivan K, et al. A Human Factors Curriculum for Surgical Clerkship Students. Archives of surgery (Chicago, III : 1960). 2010;145:1151-7.

62. Berger S, Mahler C, Krug K, Szecsenyi J, Schultz JH. Evaluation of interprofessional education: Lessons learned through the development and implementation of an inter professional seminar on team communication for undergraduate health care students in Heidelberg - A project report. GMS J Med Educ. 2016;33.

63. New SN, Huff DC, Hutchison LC, Bilbruck TJ, Ragsdale PS, Jennings JE, et al. Integrating Collaborative Interprofessional Simulation into Pre-Licensure Health Care Programs. Nurs Educ Perspect. 2015;36(6):396-7.

64. Bradley P, Cooper S, Duncan F. A mixed-methods study of interprofessional learning of resuscitation skills. Medical education. 2009;43:912-22.

65. Lin Y-C, Chan T-F, Lai C-S, Chin C-C, Chou F-H, Lin H-J. The impact of an interprofessional problembased learning curriculum of clinical ethics on medical and nursing students' attitudes and ability of interprofessional collaboration: A pilot study. The Kaohsiung journal of medical sciences. 2013;29:505-11.

66. Levett-Jones T, Gilligan C, Lapkin S, Hoffman K. Interprofessional education for the quality use of medicines: Designing authentic multimedia learning resources. Nurse education today. 2011;32.

67. Macdonnell C, Rege S, Misto K, Dollase R, George P. An Introductory Interprofessional Exercise for Healthcare Students. American journal of pharmaceutical education. 2012;76:154.

68. MacDougall C, S. Schwartz B, Kim L, Nanamori M, Shekarchian S, V. Chin-Hong P. An Interprofessional Curriculum on Antimicrobial Stewardship Improves Knowledge and Attitudes Toward Appropriate Antimicrobial Use and Collaboration. Open Forum Infectious Diseases. 2016;4:ofw225.

69. O'Carroll V, Braid M, Ker J, Jackson C. How can student experience enhance the development of a model of interprofessional clinical skills education in the practice placement setting? Journal of interprofessional care. 2012;26:508-10.

70. Patel K, Desai U, Paladine H. Development and implementation of an interprofessional pharmacotherapy learning experience during an advanced pharmacy practice rotation in primary care. Curr Pharm Teach Learn. 2018;10(7):990-5.

71. Feather R, E. Carr D, M. Garletts D, Reising D. Nursing and medical students teaming up: Results of an interprofessional project. Journal of Interprofessional Care. 2017;31:1-3.

72. Sakai DH, Marshall S, Kasuya RT, Wong L, Deutsch M, Guerriero M, et al. Medical school hotline: interprofessional education: future nurses and physicians learning together. Hawaii J Med Public Health. 2012;71(6):168-71. 
73. Chihchen Chou F, Kwan C-Y, Hsin-Chen Hsin D. Examining the effects of interprofessional problembased clinical ethics: Findings from a mixed methods study. Journal of interprofessional care. 2016;30:362-9.

74. Luctkar-Flude M, Baker C, Hopkins-Rosseel D, Pulling C, McGraw R, Medves J, et al. Development and Evaluation of an Interprofessional Simulation-Based Learning Module on Infection Control Skills for Prelicensure Health Professional Students. Clinical Simulation In Nursing. 2014;10(8):395-405.

75. Luctkar-Flude M, Baker C, Pulling C, McGraw R, Dagnone D, Medves J, et al. Evaluating an undergraduate interprofessional simulation-based educational module: Communication, teamwork, and confidence performing cardiac resuscitation skills. Advances in medical education and practice. 2010;1:59-66.

76. M. Amerongen H, Legros T, Cooley J, P. Schloss E, Theodorou A. Constructive contact: Design of a successful introductory interprofessional education experience. Currents in Pharmacy Teaching and Learning. 2015;7.

77. Anderson E, Lakhani N. Interprofessional learning on polypharmacy. The clinical teacher. 2016;13.

78. Wershofen B, Heitzmann N, Beltermann E, Fischer MR. Fostering interprofessional communication through case discussions and simulated ward rounds in nursing and medical education: A pilot project. GMS J Med Educ. 2016;33(2):Doc28-Doc.

79. Reising DL, Carr DE, Shea RA, King JM. Comparison of communication outcomes in traditional versus simulation strategies in nursing and medical students. Nurs Educ Perspect. 2011;32(5):323-7.

80. Shafran DM, Richardson L, Bonta M. A novel interprofessional shadowing initiative for senior medical students. Med Teach. 2015;37(1):86-9.

81. Sigalet E, Donnon T, Grant V. Undergraduate Students' Perceptions of and Attitudes Toward a Simulation-Based Interprofessional Curriculum The KidSIM ATTITUDES Questionnaire. Simulation in healthcare : journal of the Society for Simulation in Healthcare. 2012;7.

82. Stewart M, Purdy J, Kennedy N, Burns A. An interprofessional approach to improving paediatric medication safety. BMC Medical Education. 2010;10(1):19.

83. Stewart M, Kennedy N, Cuene-Grandidier H. Undergraduate interprofessional education using highfidelity paediatric simulation. Clin Teach. 2010;7(2):90-6.

84. M Tofil N, Morris J, Peterson D, Watts P, Epps C, F Harrington K, et al. Interprofessional simulation training improves knowledge and teamwork in nursing and medical students during internal medicine clerkship. Journal of hospital medicine : an official publication of the Society of Hospital Medicine. 2014;9.

85. Turrentine B, M. Rose K, B. Hanks J, Lorntz B, A. Owen J, Brashers V, et al. Interprofessional training enhances collaboration between nursing and medical students: A pilot study. Nurse Education Today. 2016;40:33-8.

86. Vaughn LM, Cross B, Bossaer L, Flores EK, Moore J, Click I. Analysis of an interprofessional home visit assignment: student perceptions of team-based care, home visits, and medication-related problems. Fam Med. 2014;46(7):522-6. 
87. Pathak S, Holzmueller C, B Haller K, Pronovost P. A Mile in Their Shoes: Interdisciplinary Education at the Johns Hopkins University School of Medicine. American journal of medical quality : the official journal of the American College of Medical Quality. 2010;25:462-7.

88. Ponzer S, Hylin U, Kusoffsky A, Lauffs M, Lonka K, Mattiasson A-C, et al. Interprofessional training in the context of clinical practice: Goals and students' perceptions on clinical education wards. Medical education. 2004;38:727-36.

89. Elizabeth Ann King A, Conrad M, A Ahmed R. Improving collaboration among medical, nursing and respiratory therapy students through interprofessional simulation. Journal of interprofessional care. 2012;27.

90. Kent F, Martin N, Keating JL. Interprofessional student-led clinics: An innovative approach to the support of older people in the community. J Interprof Care. 2016;30(1):123-8.

91. Ericson A, Masiello I, Bolinder G. Interprofessional clinical training for undergraduate students in an emergency department setting. Journal of interprofessional care. 2012;26:319-25.

92. Hallin K, Kiessling A, Waldner A, Henriksson P. Active interprofessional education in a patient based setting increases perceived collaborative and professional competence. Med Teach. 2009;31(2):1517.

93. Hallin K, Henriksson P, Dalen N, Kiessling A. Effects of interprofessional education on patient perceived quality of care. Med Teach. 2011;33(1):e22-6.

94. Mitchell M, Groves M, Mitchell C, Batkin J. Innovation in learning - An inter-professional approach to improving communication. Nurse education in practice. 2010;10:379-84.

95. Meffe F, Moravac C, Espin S. An interprofessional education pilot program in maternity care: Findings from an exploratory case study of undergraduate students. Journal of interprofessional care. 2012;26:183-8.

96. Lie D, Forest C, Walsh A, Banzali Y, Lohenry K. What and How Do Students Learn in an Interprofessional Student-Run Clinic? An Educational Framework for Team-Based Care. Medical Education Online. 2016;21.

97. Sick B, Sheldon L, Ajer K, Wang Q, Zhang L. The student-run free clinic: An ideal site to teach interprofessional education? Journal of interprofessional care. 2014;28.

98. Rotz M, Dueñas G. "Collaborative-ready" students: Exploring factors that influence collaboration during a longitudinal interprofessional education practice experience. Journal of interprofessional care. 2016;30:1-4.

99. Street KN, Eaton N, Clarke B, Ellis M, Young PM, Hunt L, et al. Child disability case studies: an interprofessional learning opportunity for medical students and paediatric nursing students. Med Educ. 2007;41(8):771-80.

100. Salvatori P, Mahoney P, Delottinville C. An interprofessional communication skills lab: A pilot project. Education for health (Abingdon, England). 2006;19:380-4.

101. Reeves SA, Denault D, Huntington JT, Ogrinc G, Southard DR, Vebell R. Learning to Overcome Hierarchical Pressures to Achieve Safer Patient Care: An Interprofessional Simulation for Nursing, 
Medical, and Physician Assistant Students. Nurse Educ. 2017;42(5S Suppl 1):S27-s31.

102. Morison S, Jenkins J. Sustained effects of interprofessional shared learning on student attitudes to communication and team working depend on shared learning opportunities on clinical placement as well as in the classroom. Medical teacher. 2007;29:464-70.

103. Maraccini A, Ramona H, Kemmelmeier M, Piasecki M, D. Slonim A. An inter-professional approach to train and evaluate communication accuracy and completeness during the delivery of nurse-physician student handoffs. Journal of Interprofessional Education \& Practice. 2018;12:65-72.

104. Boehler ML, Schwind CJ, Markwell SJ, Minter RM. Mock Pages Are a Valid Construct for Assessment of Clinical Decision Making and Interprofessional Communication. Ann Surg. 2017;265(1):116-21.

105. J. Arumpanayil A, Winkelman C, K. McConnell K, R. Pelyak M, P. Brandt C, M. Lipman J. Attitudes Toward Communication and Collaboration After Participation in a Mock Page Program: A Pilot of an Interprofessional Approach to Surgical Residency Preparation. Journal of Surgical Education. $2018 ; 75$.

106. Berg B, Wong L, S Vincent D. Technology-enabled interprofessional education for nursing and medical students: A pilot study. Journal of interprofessional care. 2010;24:601-4.

107. Holland C, Bench S, Brown K, Bradley C, Johnson L, Frisby J. Interprofessional working in acute care. Clin Teach. 2013;10(2):107-12.

108. Leann Horsley T, Reed T, Muccino K, Quinones D, Siddall V, McCarthy J. Developing a Foundation for Interprofessional Education Within Nursing and Medical Curricula. Nurse Educator. 2016;41:1.

109. Jakobsen R, Gran S, Grimsmo B, Arntzen K, Fosse E, Frich J, et al. Examining participant perceptions of an interprofessional simulation-based trauma team training for medical and nursing students. Journal of Interprofessional Care. 2017;32:1-9.

110. Wagner J, Liston B, Miller J. Developing interprofessional communication skills. Teaching and Learning in Nursing. 2011;6:97-101.

111. Oxelmark L, Amorøe T, Carlzon L, Rystedt H. Students' understanding of teamwork and professional roles after interprofessional simulation-a qualitative analysis. Advances in Simulation. 2017;2.

112. Robertson B, Kaplan B, Atallah H, Higgins M, Lewitt MJ, Ander DS. The use of simulation and a modified TeamSTEPPS curriculum for medical and nursing student team training. Simul Healthc. 2010;5(6):332-7.

113. K. Oza S, Wamsley M, Boscardin C, Batt J, Hauer K. Medical students' engagement in interprofessional collaborative communication during an interprofessional observed structured clinical examination: A qualitative study. Journal of Interprofessional Education \& Practice. 2017;7:21-7.

114. Andersen P, Coverdale S, Kelly M, Forster S. Interprofessional Simulation: Developing Teamwork Using a Two-Tiered Debriefing Approach. Clinical Simulation in Nursing. 2018;20:15-23.

115. House J, Cedarbaum J, Haque F, Wheaton M, Vredeveld J, Purkiss J, et al. Medical student perceptions of an initial collaborative immersion experience. Journal of Interprofessional Care. $2017 ; 32$. 
116. Eich-Krohm A, Kaufmann A, Winkler Stuck K, Werwick K, Spura A, Robra BP. First Contact: interprofessional education based on medical students' experiences from their nursing internship. GMS J Med Educ. 2016;33.

117. Hudson JN, Lethbridge A, Vella S, Caputi P. Decline in medical students' attitudes to interprofessional learning and patient-centredness. (1365-2923 (Electronic)).

118. Wright A, Hawkes G, Baker B, Lindqvist S. Reflections and unprompted observations by healthcare students of an interprofessional shadowing visit. Journal of interprofessional care. 2012;26:305-11.

119. V. Kusnoor A, A. Stelljes L. Interprofessional learning through shadowing: Insights and lessons learned. Medical Teacher. 2016;38:1-7.

120. Jain A, Luo E, Yang J, Purkiss J, White C. Implementing a Nurse-Shadowing Program for First-Year Medical Students to Improve Interprofessional Collaborations on Health Care Teams. Academic medicine : journal of the Association of American Medical Colleges. 2012;87:1292-5.

121. Clarke $\mathrm{H}$, Voss $\mathrm{M}$. The role of a multidisciplinary student team in the community management of chronic obstructive pulmonary disease. Primary Health Care Research \& Development. 2016;-1:1-6.

122. Creswell JW, Miller DL. Determining Validity in Qualitative Inquiry. Theory Into Practice. 2000;39(3):124-30.

123. Mennin S. Self-organisation, integration and curriculum in the complex world of medical education. Medical education. 2010;44(1):20-30.

124. Lannin DG, Tucker JR, Streyffeler L, Harder S, Ripley B, Vogel DL. How Medical Students' Compassionate Values Influence Help-Seeking Barriers. Teach Learn Med. 2019;31(2):170-7.

\section{Figures}




\section{Figure 1:}

Database search:

(Physicians) AND (Interprofessional Relations)

AND (Communication) from year 2000-2018

- PubMed: 4929

- Embase: 13688

- ERIC: 293

- CINAHL: 2200

- Scopus: 172

- PsycINFO: 1568

- JSTOR: 216

- Google Scholar: 124

Additional records identified through other sources:

0 article

Excluded 5381 duplicate articles

\section{7,493 full text articles}

Excluded non-relevant articles based on title and abstract (e.g. not about intervrofessional communications)

\section{0 full-text articles}

Excluded articles based on exclusion criteria

- Complementary medicine, non-medical specialties (e.g. Veterinary and Dentistry) and physicians outside of the EM scope

- Assessment tools on multidisciplinary communication

- Pedagogy strategies in educating other healthcare providers towards communicating with physicians

70 articles included

\section{Figure 1}

PRISMA Flowchart 


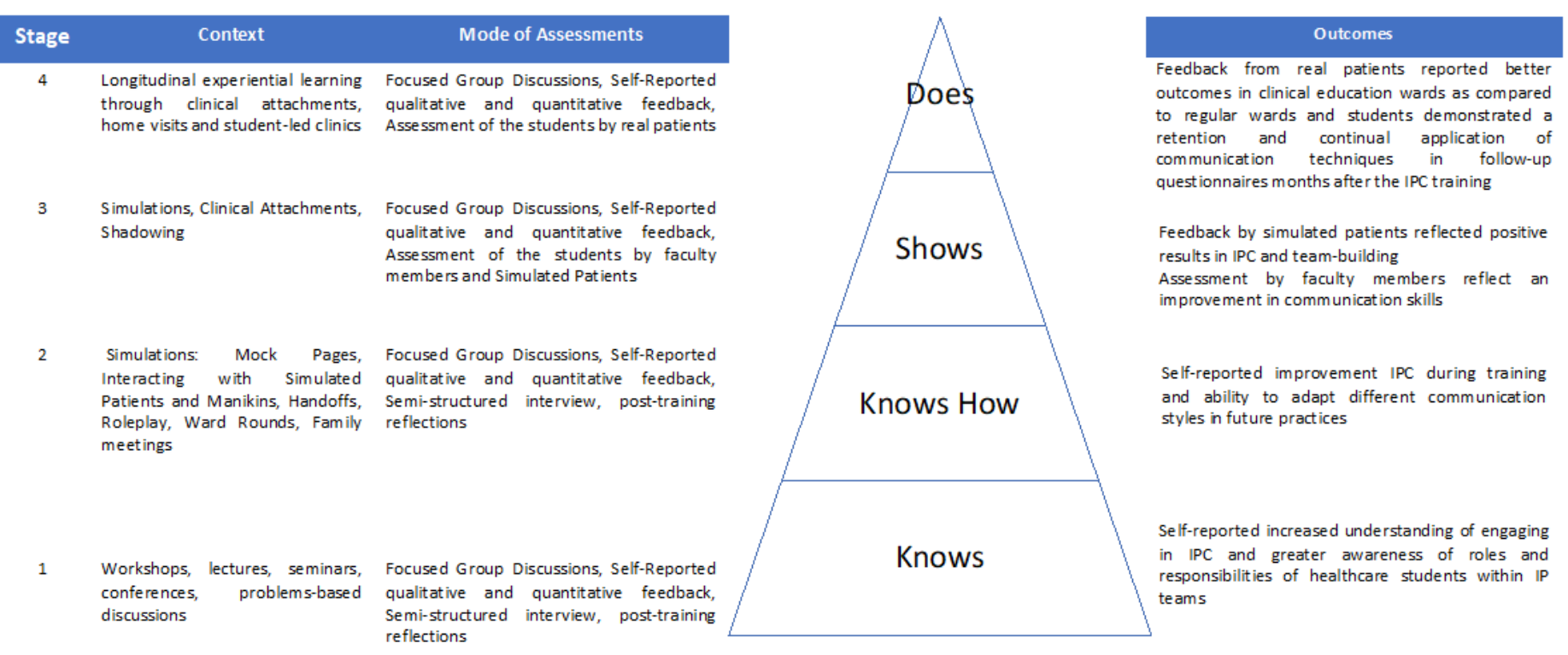

\section{Figure 2}

Miller's Pyramid of Included Articles

\section{Supplementary Files}

This is a list of supplementary files associated with this preprint. Click to download.

- SupplementaryFile1PubMedSearchStratergy.docx

- PRISMA2009checklist.pdf 